Original Research

\title{
Characterization and identification of Pseudo-nitzschia species in Lampung Bay, Indonesia
}

\author{
Arief Rachman*, Hikmah Thoha \\ Research Center for Oceanography, National Research and Innovation Agency (RCO-BRIN), Jl. Pasir Putih I No.1, Ancol Timur, Jakarta Utara, \\ 14430, Indonesia
}

\begin{tabular}{|c|c|}
\hline ARTICLE INFO & ABSTRACT \\
\hline Article history: & \multirow{11}{*}{$\begin{array}{l}\text { Pseudo-nitzschia species have received more attention in recent decades due to increasing Amnesic } \\
\text { Shellfish Poisoning (ASP) cases in many Asian countries caused by the toxic domoic acid they } \\
\text { produced. However, information on morphological characters of Pseudo-nitzschia species in } \\
\text { Indonesia was very limited, which hinders the attempt to quickly identify the species during } \\
\text { Harmful Algal Blooms (HABs) in the coastal waters. Thus, this study aimed to identify and } \\
\text { characterize the Pseudo-nitzschia species found in Lampung Bay, Indonesia. Phytoplankton samples } \\
\text { used in this study were taken from the reference collection for plankton (RCP) in the Research } \\
\text { Center for Oceanography, National Research and Innovation Agency (RCO-BRIN). The original } \\
\text { samples were collected from Hurun Bay, Padang Cermin, Lampung, during high tide in } 2005 \text {. } \\
\text { In this research, morphology and morphometry of Pseudo-nitzschia were observed using a light } \\
\text { microscope (LM) and transmission electron microscope (TEM). The Pseudo-nitzschia species } \\
\text { found in Lampung was labelled as LMP3. Jaccard cluster analysis, using the simple average link, } \\
\text { showed that LMP3 was Pseudo-nitzschia pungens. The morphology and morphometry of LMP3 } \\
\text { were matched perfectly with P. pungens (100\% similarity) and differed from other Pseudo-nitzschia } \\
\text { species in Seriata complex. Unfortunately, it was not known whether the P. pungens LMP3 in this } \\
\text { study was the toxin producer strain as this study used preserved sample, thus it was not possible to } \\
\text { detect any trace of domoic acid in there. }\end{array}$} \\
\hline Submitted 11 September 2021 & \\
\hline Revised 22 November 2021 & \\
\hline Accepted 30 November 2021 & \\
\hline Published online 3 December 2021 & \\
\hline Keywords: & \\
\hline diatom, & \\
\hline Pseudo-nitzschia, & \\
\hline taxonomy, & \\
\hline TEM, & \\
\hline morphology and morphometry & \\
\hline
\end{tabular}

(C2021 Indonesian Institute of Sciences (LIPI)

\section{Introduction}

Chain-forming, pennate marine diatom genus Pseudo-nitzschia Peragallo is a typical component of marine phytoplankton communities, which can be found abundant in inshore, offshore and oceanic ecosystems in all biogeographic zones (HernándezBecerril, 1998; Hasle et al., 1996; Orsini et al., 2002; Casteleyn et al., 2008). Recently, the genus has received more attention, mainly due to the ability of some Psendo-nitzschia species that are capable on produce domoic acid, a neurotoxin responsible for amnesic shellfish poisoning (ASP) (Casteleyn et al., 2008; Hasle et al., 1996; Orsini et al., 2002).

In the past, most phytoplankton taxonomists classify Pseudo-nitzschia as part of genus Nitzschia Hassal due to the limitation of microscopy equipment available at that time. However, observation using an electron microscope managed to separate Pseudo-nitzschia into different genera due to its differences in morphological and morphometrical characters with Nitschia (Skov, et al., 1999; Hasle et al., 1996). A similar case also occurred in Indonesia, where most of the researchers classify Pseudo-nitzschia as Nitzschia genus, which was also commonly found in coastal ecosystems (Sidabutar, 2010; Thoha, 2010).

In general, species of Pseudo-nitzschia was divided into 2 major groups based on the cell width, which were: the Seriata complex and the Delicatissima complex (Hasle et al., 1996; Skov et al., 1999). The Seriata complex has a valve width of around 3- $4 \mu \mathrm{m}$ or more, while the Delicatissima complex has a valve width less than 3 - $4 \mu \mathrm{m}$ (Hasle et al., 1996; Skov et al., 1999).

Pseudo-nitzschia characters that could be observed under a light microscope (LM) were: (1) cell width, (2) cell length, (3) cell shape, (4) shape of cell or valve, (5) central nodule, (6) visibility of fibulae and interstriae, (7) cell overlap in the chain (Hernández-Becerril, 1998; Casteleyn et al., 2008; Hasle et al., 1996; Skov et al., 1999; UNESCO/IOC/WESTPAC, 2011). However, identification of Pseudo-nitzschia at species level using only LM was difficult. Some species such as Pseudo-nitzschia pungens, $P$. seriata, $P$. multiseries, $P$. australis, and $P$. pungiformis have similar morphological characters which were difficult to distinguish under light microscopy (Hernández-Becerril, 1998; Hasle et al., 1996). P. pungens was often confused with P. seriata when seen in girdle view due to highly similar fibulae structure (Hasle et al., 1996). In girdle view, P. pungens also can hardly be distinguished from $P$. multiseries. Meanwhile, $P$. pungiformis has a similar valve outline as $P$. pungens and $P$. multiseries, but it has a larger central interspace and has a central nodule (Hasle et al., 1996). Variation of cell's morphological characters in natural samples due to vegetative cell division, or due to environmental stress, could also lead to misidentification of Psendo-nitzschia species. (Cerino et al., 2005; Thessen et al., 2005).

\footnotetext{
* Corresponding Author

Arief Rachman, arief_rachman1987@yahoo.com
} 
Observation with Scanning Electron Microscope (SEM) or Transmission Electron Microscope (TEM), revealed more specific characters that could be used to identify Pseudo-nitzschia species up to species level. Characters that could be observed under TEM microscopy were: (1) density of fibulae per $10 \mu \mathrm{m}$, (2) density of interstriae per $10 \mu \mathrm{m},(3)$ number or poroids row, (4) structure of poroid (Hernández-Becerril, 1998; Casteleyn et al., 2008; Hasle et al., 1996; Skov et al., 1999; UNESCO/ IOC/WESTPAC, 2011). A combination of characters that were observed under LM and TEM were commonly used in Pseudo-nitzschia identification at the species level. However, more recent phylogenetic studies using DNA sequence was frequently favoured to identify the Pseudo-nitzschia up to sub-species level (Casteleyn et al., 2008).

Specific studies of Pseudo-nitzschia species in Indonesia were rare and most studies were focused on the distribution and abundance of the genus in marine ecosystems. Similarly, taxonomic studies of Pseudo-nitzschia species were rarely conducted, therefore information on Pseudo-nitzschia species found in Indonesian water was very limited. Thus, this study was aimed to (1) identify a common Pseudo-nitzschia species found in the preserved samples from Lampung Bay; and (2) understand the morphological and morphometrical character of Pseudo-nitzschia found in Lampung Bay, Indonesia.

\section{Materials and Method}

\subsection{Sample Origins}

Pseudo-nitzschia specimens were taken from preserved samples stored in the Reference Collection for Plankton (RCP) of the Plankton Productivity Laboratory, Research Center for Oceanography, National Research and Innovation Agency (RCO-BRIN). The samples were collected in fieldwork in 2005 during high tide, using Kitahara plankton net (mesh size $80 \mu \mathrm{m}$ ), in Hurun Bay, Padang Cermin district, Lampung, Indonesia (Figure 1). All samples were preserved in $4 \%$ formaldehyde ( $\mathrm{v} / \mathrm{v})$. The samples from Hurun Bay, Padang Cermin, Lampung were selected by taking into account the high density of Nitzschia
(Pseudo-nitzschia) cells in the observation data of samples from the adjacent areas within the Lampung Bay during 2005 field sampling.

\subsection{Sample Preparation and Observation}

Morphological and morphometrical analysis of Pseudo-nitzschia species found in samples was conducted with a light microscope (LM) and transmission electron microscope (TEM), using noncleaned and acid cleaned materials. The non-cleaned material was obtained directly from the preserved sample, then was transferred to Sedgewick Rafter Counting Chamber (SRCC) for observation. Observation of non cleaned Pseudo-nitzschia species by light microscopy was conducted using an inverted microscope Nikon Diaphot model 108 under 200 - 400X magnification. The phase-contrast illumination technique was used to increase the contrast of the non-cleaned Pseudo-nitzschia samples. LM images taken with Canon EOS 500D mounted on Nikon Diaphot using Nikon F to Canon EF mount adapter. On the other hand, the acid cleaned material was obtained after cleaning all organic material in the sample. The acid cleaning process was conducted following the diatom cleaning and electron microscopy preparation methods described by G.R. Hasle in Sournia (1976). The acid cleaned sample was then placed on a copper grid coated with a Formvar film. JEOL JEM-12 TEM microscope in Universiti Malaysia Sarawak, Malaysia was used to observe Pseudo-nitzschia nanostructures under 10.000 - 300.000X magnification. As a note, some images shown in the Result section have been published in Rachman (2013) (Figure 2A, 3A, 3B, 3D) and Bayu et al. (2020) (Figure 3A, 3D). For this study, those images were then modified by adding arrows, lines, and letters to point out some specific morphological and morphometrical characters of the Psendo-nitzschia LMP3 frustule.

Specific taxonomic characters, as described earlier in the Introduction section, were used for species-level identification of the Pseudo-nitzschia cells in this study (Hernández-Becerril, 1998; Casteleyn et al., 2008; Hasle et al., 1996). The most common Pseudo-nitzschia species found in the sample of

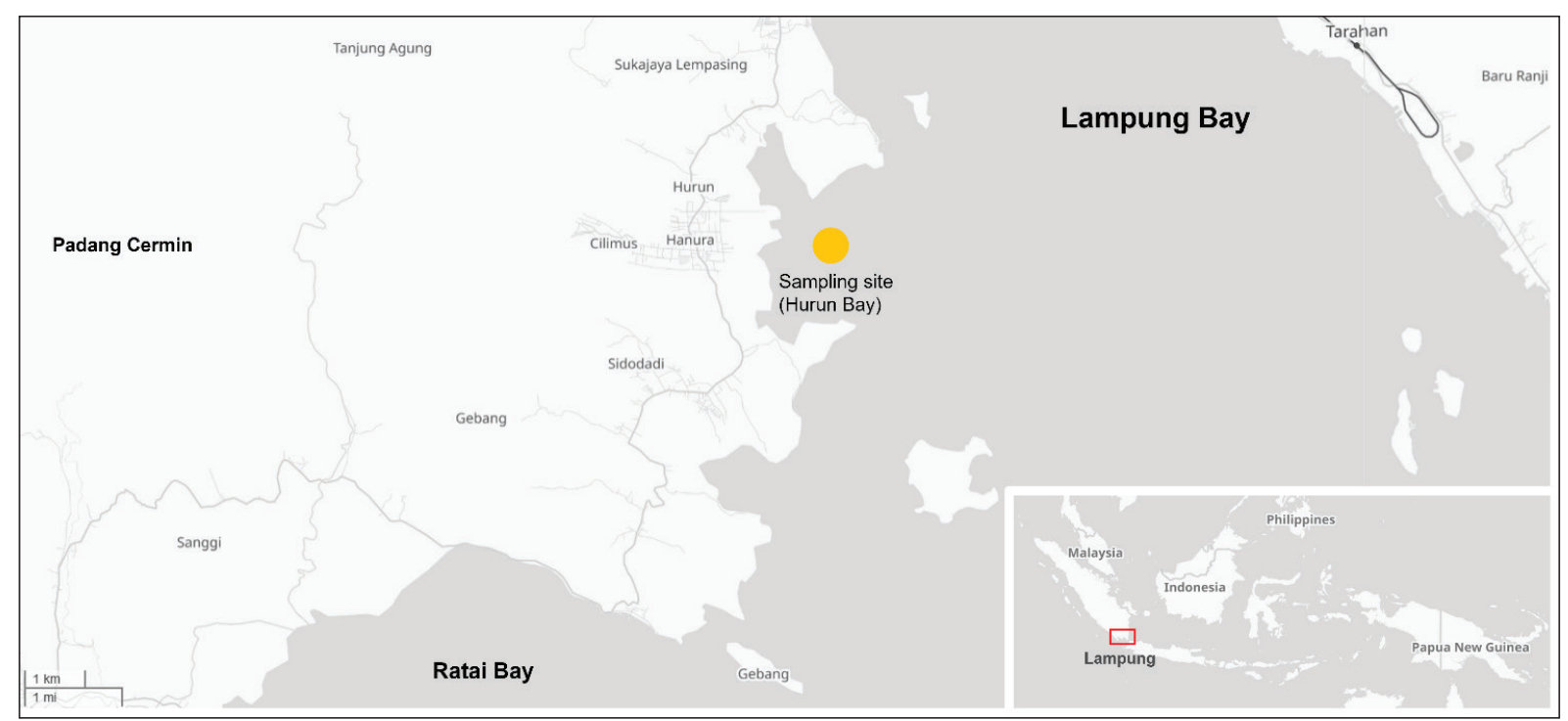

Figure 1. Location of the sampling site from which the preserved Pseudo-nitzschia samples were originated. Samples were collected during fieldwork in 2005. 
this study was labelled as Psendo-nitzschia LMP3 or LMP3. Taxonomic characters of LMP3 were then compared to other Pseudo-nitzschia species in both Seriata and Delicatissima complex (Hasle et al., 1996; Skov et al., 1999; UNESCO/ IOC/WESTPAC, 2011). Taxonomic information, particularly, systematic classification follows the most recent information on Algaebase website (Guiry \& Guiry, 2020).

\subsection{Data Analysis}

Taxonomic data, consisting of morphology and morphometric characters of Pseudo-nitzschia, were then analyzed with Jaccard cluster analysis (simple average link) to determine the similarity of the characters with other species within the Seriata and Delicatissima complex. The clustering analysis was done using BioDiversity Professional Ver.2 statistic program (Guiry \& Guiry, 2020).

\section{Result}

\subsection{Systematic account and descriptions of Pseudo- nitzchia pungens}

Pseudo-nitzschia pungens (Grunow ex. Cleve) Hasle,

(Hasle, 1993; Hallegraeff, 1994; Hasle et al., 1996; Skov et al., 1999)

Synonym: Nitzschia pungens Grunow ex. Cleve

(Cupp, 1943; Rivera, 1985)

\section{Systematic classification}

(Guiry \& Guiry, 2020)

Empire : Eukaryota

Kingdom : Chromista

Phylum : Bacillariophyta

Subphylum : Bacillariophytina

Class : Bacillariophyceae

Subclass : Bacillariophycidae

Order : Bacillariales

Family : Bacillariaceae

Genus : Pseudo-nitzschia

Species : Pseudo-nitzschia pungens (Grunow ex. Cleve) Hasle

\subsubsection{Light microscopy characters}

Cells formed a chain-shaped colony. Cells in the chain overlapped $\pm 1 / 3$ of cell length. The valve is symmetric, with a linear to lanceolate shape. The ends of the valve were pointed. The cells were strongly silicified, thus the interstriae and fibulae were visible in fresh and acid cleaned material. However, the interstriae is often coarsely silicified so it is difficult to differentiate fibulae from interstriae. In fresh material, two chloroplasts sometimes could be seen inside the cell. Cell length around 24-121 $\mu \mathrm{m}$, and cell width around $2.4-4.2 \mu \mathrm{m}$ (Skov et al., 1999; UNESCO/ IOC/WESTPAC, 2011). The central nodule is absent.

\subsubsection{TEM microscopy characters:}

Fibulae and interstriae have relative equal densities with a ratio of $1: 1$. The density of fibulae is $8-14$ in $10 \mu \mathrm{m}$ and the density of interstriae is $8-13$ in $10 \mu \mathrm{m}$. There are 2 rows of poroids (striae) in between two interstriae, sometimes it has 1 additional row of poroids. The density of poroids is $2-4$ poroids in $1 \mu \mathrm{m}$. The valve end often has fewer poroids per striae than the other. The structure of poroids is simple and hymenate, usually perforated by closely packed holes in a hexagonal array.

\subsection{Characters and identification of Pseudo- nitzschia LMP3}

In water mounted sample under phase-contrast light microscopy, the Pseudo-nitzschia cells of LMP3 appears to have a lanceolate shape and exhibit longitudinal symmetry (Figure 2A). The central nodule was absent in all cells in the sample. The bands of striae and interstriae, also the preserved chloroplast, were often observable in the non-cleaned water mount samples (Figure 2B). In LMP3 specimens, the fibulae were barely observable in the water mount at $400 \mathrm{X}$ magnification (Figure 2). The Pseudonitzschia cells of LMP3 form a chain-shaped colony, with each cell overlapping each other about 1/4 of cell length (Figure 2A).

The length of LMP3 Psendo-nitschia cells was varied between 70.5 to $93.4 \mu \mathrm{m}$, while the cell width was varied between 2.4 to $3.6 \mu \mathrm{m}$. Those morphological and morphometric characteristics were similar to the character of $P$. pungens (Table 1). However, it is important to note that other Pseudo-nitzschia species, particularly $P$. seriata, also have similar morphological and morphometric characteristics when observed under LM in a water mount. Thus, it was very difficult to confidently classify
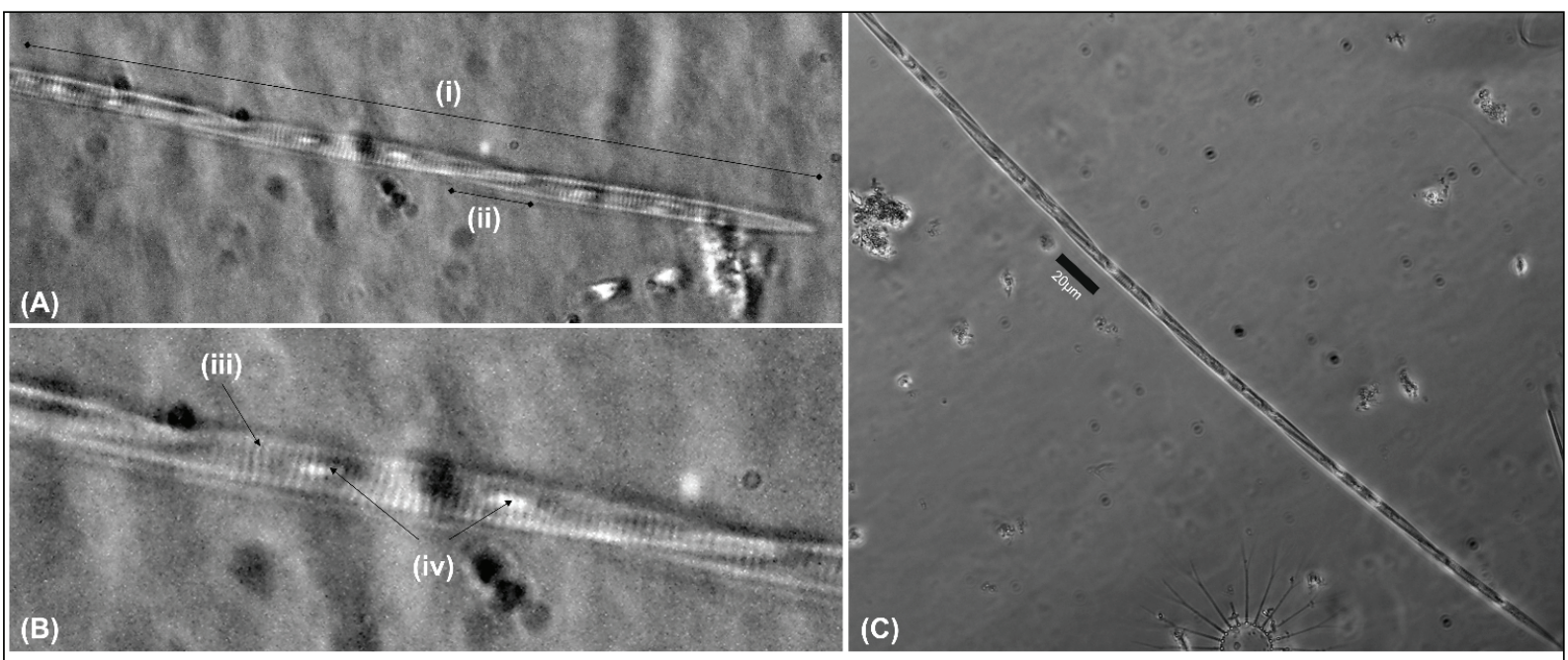

(iii)

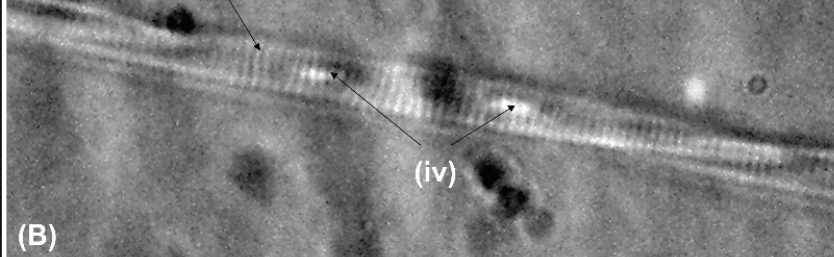

(C)

Figure 2. Psendo-nitzschia LMP3 in water mount under the light microscope (LM) with phase-contrast lighting. (A) Cells observed at 400X magnification; (B) digitally cropped and magnified image showing details of a single cell within the chain colony; (C) chain colony viewed under lower magnification (200X). (i) whole chain colony; (ii) overlapping at cell ends; (iii) striae and interstriae (spaces between striae); (iv) preserved chloroplast. Image A and B without scale. Images A and B were taken and modified from Rachman (2013). 

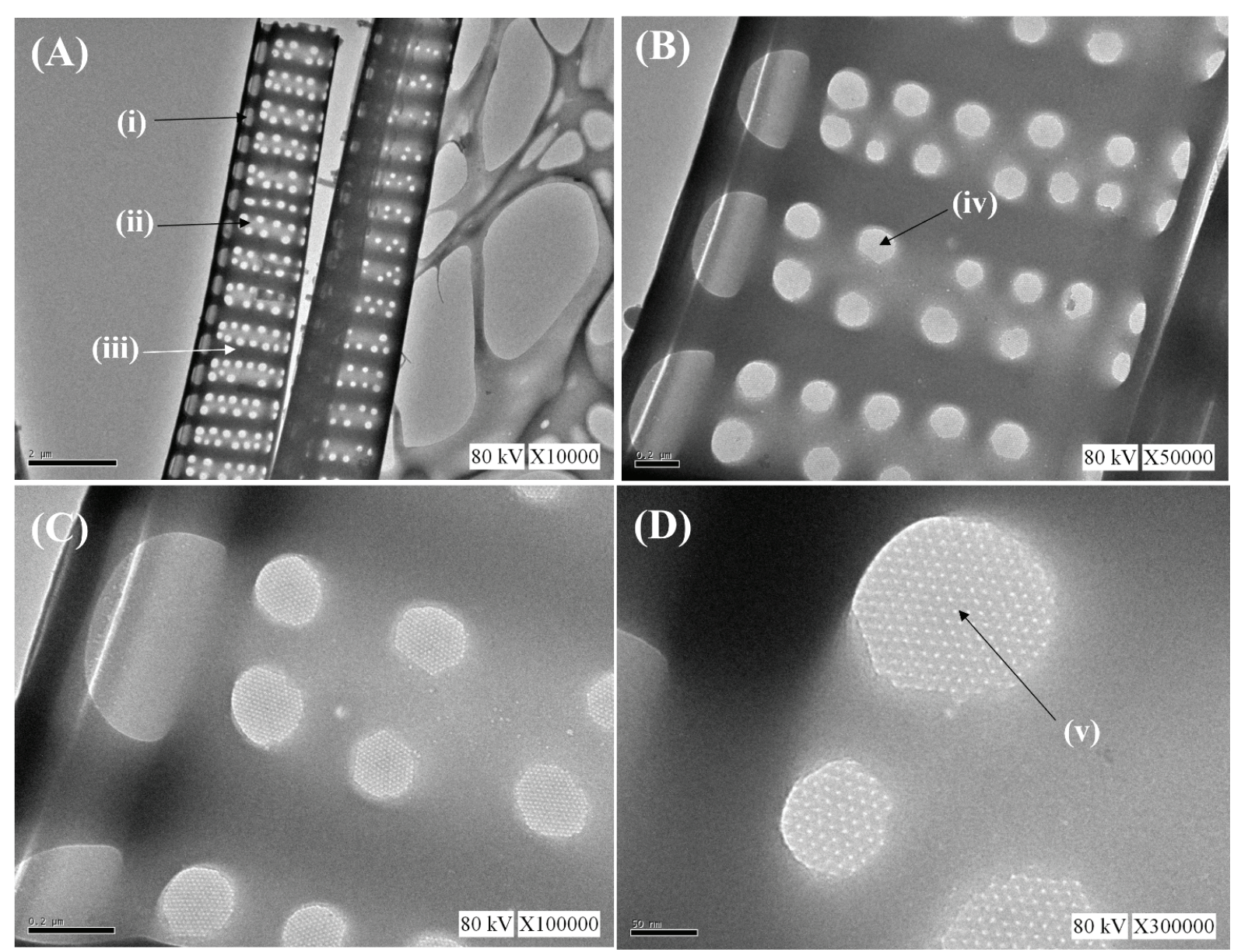

Figure 3. Pseudo-nitzschia LMP3 under electron microscope. (A) TEM image of $P$. pungens (LMP3) valve, revealing the number of poroids rows and density of poroids; (B) Details of the valve under 50.000X magnification; (D) Details of the valve under 100.000X magnification; (D) Details of poroids structure. (i) fibulae; (ii) striae with two rows of poroids; (iii) inter-striae; (iv) poroid; (v) hymen, an ultra/nanostructure within each poroid. Scale bars $=$ (A) $2 \mu \mathrm{m}$; (B) $0.2 \mu \mathrm{m}$;(C) $0.2 \mu \mathrm{m} ; 50 \mathrm{~nm}$ (E). Images A, B, and D were taken and modified from Rachman (2013) and Bayu et al. (2020).

Pseudo-nitzschia LMP3 as P. pungens or P. seriata by using only its key characters that were observable under LM.

The result from TEM analysis (Figure 3B - 3E) revealed more details on the morphological characters of Pseudo-nitzschia LMP3, as well as some of its valve's nanostructures. As seen in Figures $2 \mathrm{~B}$ and $2 \mathrm{C}$, the density of fibulae and striae were equal, with 13 fibulae and 13 striae per $10 \mu \mathrm{m}$. However, further examination in some other Pseudo-nitzschia LMP3 cells shows the unequal density of fibulae and striae. The Pseudo-nitzschia LMP3 cells generally have two rows of poroids, although there was a striae with only one row of poroids (Figure $3 \mathrm{~A}$ ). The density of the poroids in Pseudo-nitzschia LMP3 cell was 4 poroids per $1 \mu \mathrm{m}$ (Figure 3A). It appears that the rows of poroids in one striae often didn't have the same number between the first and second row. In Pseudo-nitzschia LMP3 cell, the number of the poroids in one row are higher than the other rows (Figure $3 \mathrm{~A}$ and $3 \mathrm{~B}$ ). The structure of the poroid is simple (Figure 3D) and the poroids are hymenate and perforated by closely packed holes in a hexagonal array (Figure 3D).

The result of TEM and LM observation highly suggested that the Pseudo-nitzschia species found in Lampung (LMP3) was Pseudo-nitzschia pungens. The morphological and morphometric characters of Pseudo-nitzschia LMP3 specimens were matched perfectly with $P$. pungens as described in Skov et al. (1999), Skov et al. (1999); Hasle et al. (1996), and Skov et al. (1999). All specific characters of $P$. pungens were observed in Pseudo-nitschia LMP3 and were different from other similar Pseudo-nitzschia species in the Seriata complex, such as P. seriata (Table 1).

\subsection{Jaccard cluster analysis on Pseudo-nitzschia LMP3 and other Pseudo-nitzschia species in the Seriata complex}

The result of Jaccard clustering analysis (simple average link) showed that the Pseudo-nitzschia LMP3 was P. pungens, with $100 \%$ similarity in its morphology and morphometry (Figure 4). Pseudo-nitzschia LMP3 also has a high similarity with $P$. multiseries, and $P$. australis, with a similarity percentage of $54.12 \%$ (Figure 4). Those similarities were mainly due to the equal density of the striae and fibulae in their valve (cells) (Table $1)$. The clustering analysis also showed that $P$. seriata was in the same group with Pseudo-nitzschia LMP3, P. pungens, $P$. multiseries, and $P$. australis (Figure 4). However, P.seriata was slightly separated from other species in the same group (Figure $4)$, mainly due to the higher density of poroids present in its valve (Table 1). The group of LMP3, P. pungens, P. multiseries, $P$. australis, and $P$. seriata, were separated from groups of $P$. pungiformis, $P$. fraudulenta, $P$. subfraudulenta, $P$. subpasifica, and $P$. heimii (Figure 4), mainly due to the lack of central nodule in the valve (Table 1). 
Table 1. Comparison of key morphologic and morphometric character between Pseudo-nitzschia LMP3 and other Pseudo-nitzschia species in Seriata complex.

\begin{tabular}{|c|c|c|c|c|c|c|}
\hline Characters & LMP3 & P. Pungens* & P. seriata* & P. multiseries ${ }^{*}$ & P. pungiformis* & P. australis* \\
\hline Valve shape & Linear-lanceolate & Linear-lanceolate & Lanceolate & Lanceolate & Linear-lanceolate & Lanceolate \\
\hline Valve symmetricity & Symmetric & Symmetric & Asymmetric & Symmetric & Symmetric & Asymmetric \\
\hline Central nodule & - & - & - & - & + & - \\
\hline Length $(\mu \mathrm{m})$ & $70.5-93.4$ & $24-121$ & $61-100$ & $67-140$ & $96-145$ & $82-144$ \\
\hline Width $(\mu \mathrm{m})$ & $2.4-3.6$ & $2.4-4.2$ & $4-8$ & $5-7$ & $5-6$ & $4-5$ \\
\hline Cell overlap in chain & $1 / 4$ & $1 / 3-1 / 4$ & $1 / 3-1 / 4$ & $N d$ & nd & $1 / 3-1 / 4$ \\
\hline Number of fibulae in $10 \mu \mathrm{m}$ & $13-14$ & $8-14$ & $14-18$ & $10-15$ & $12-18$ & $12-18$ \\
\hline Number of striae in $10 \mu \mathrm{m}$ & $12-13$ & $8-13$ & $14-18$ & $10-15$ & $14-20$ & $12-18$ \\
\hline Row of poroids & 2 & 2 & $2+1(-2)$ & $3-4(5)$ & 2 & 2 \\
\hline Number of poroids in $1 \mu \mathrm{m}$ & $3-4$ & $2-4$ & $7-8$ & $5-7$ & $5-6$ & $4-5$ \\
\hline Complexity of poroids & Simple & Simple & Simple & Simple & Simple & Simple \\
\hline \multicolumn{7}{|c|}{$\begin{array}{l}\text { Table } 1 \text { (Continued). Comparison of key morphologic and morphometric character between Psendo-nitzschia LMP3 and other Pseudo-nitzschia } \\
\text { species in Seriata complex. }\end{array}$} \\
\hline Characters & LMP3 & P. fraudulenta* & P. sub & audulenta* & P. subpasifica* & P. heimii* \\
\hline Valve shape & Linear-lanceolate & Lanceolate & Linea & anceolate & Lanceolate & Linear-lanceolate \\
\hline Valve symmetricity & Symmetric & Symmetric & Symm & & Asymmetric & Symmetric \\
\hline Central nodule & - & + & + & & + & + \\
\hline Length $(\mu \mathrm{m})$ & $70.5-93.4$ & $50-119$ & $65-10$ & & $33-70$ & $50-120$ \\
\hline Width $(\mu \mathrm{m})$ & $2.4-3.6$ & $4-7$ & $4.8-7$ & & $9-10$ & $5-8$ \\
\hline Cell overlap in chain & $1 / 4$ & $n d$ & nd & & $1 / 5-1 / 6$ & $1 / 4-1 / 5$ \\
\hline Number of fibulae in $10 \mu \mathrm{m}$ & $13-14$ & $12-24$ & $12-17$ & & $15-20$ & $11-18$ \\
\hline Number of striae in $10 \mu \mathrm{m}$ & $12-13$ & $18-24$ & $23-28$ & & $28-32$ & $19-28$ \\
\hline Row of poroids & 2 & $2-3$ & 2 & & 2 & $1-2$ \\
\hline Number of poroids in $1 \mu \mathrm{m}$ & $3-4$ & $4-7$ & $5-6$ & & $9-10$ & $5-8$ \\
\hline Complexity of poroids & Simple & Complex & Comp & & Simple & Simple \\
\hline
\end{tabular}

Note: $n d=$ no data; ${ }^{*}$ Morphology and morphometry data based on Skov et al. (1999) and UNESCO/IOC/WESTPAC (2011)

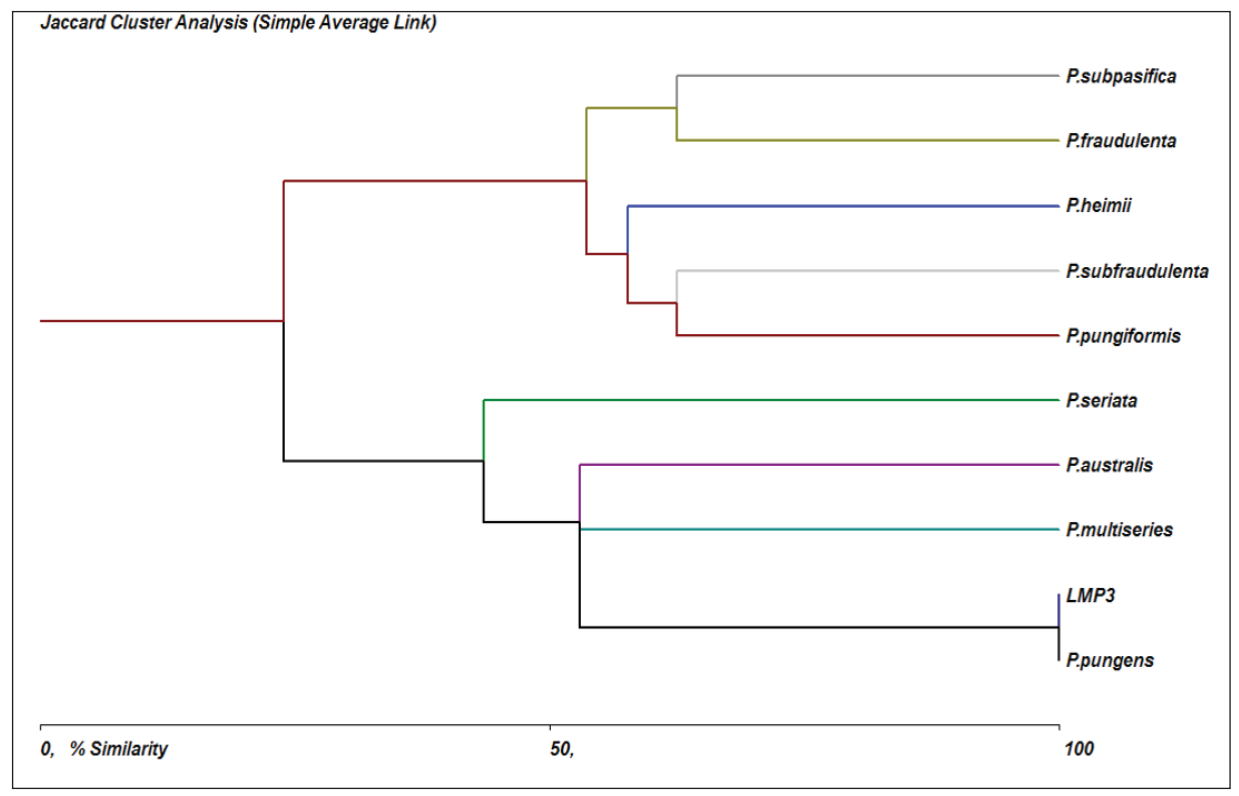

Figure 4. Jaccard cluster analysis (simple average link) on Pseudo-nitzschia LMP3 and other Psendo-nitzschia species in seriata complex. Morphometric and morphological characters were used in this analysis. Binomial code ( 1 and 0$)$ were used to substitute the presence or absence of characters in the specimens. 


\section{Discussion}

\subsection{Comparison of P. pungens LMP3 characters with other species in seriata complex}

Under light microscopy (LM), it was very difficult to distinguish each species in the Seriata complex, mainly due to the high similarity in their cell's morphological characters. For example, $P$. pungens and P. seriata both have similar cell outlines and also have a similar density of fibulae and striae when observed under LM. Thus, in the past, those species were considered as a different form of the same species (Orsini et al., 2002). Additionally, due to its morphological similarity, Psendo-nitzschia used to be classified under the genus Nitzschia but later was separated from that genus due to the ability of most Pseudo-nitzschia species to form chain colonies (Lelong et al., 2012).

In higher magnification using TEM, the difference in some specific cell characters serves as a base to separating the $P$. pungens and P. seriata as different species. Although both species appear similar under LM, the shape of $P$. seriata cell or valve was always lanceolate and appear asymmetric (Table 1) compared to $P$. pungens. Both $P$. seriata and $P$.pungens have a relatively equal number of striae and fibulae. However, the density of poroids in $P$. seriata is higher than the $P$. pungens (Table 1 ). On the other hand, $P$. multiseries also have a similar cell outline to $P$. pungens and was very hard to be distinguished under LM.

Observation with TEM showed that P. multiseries have a higher number in the row of poroids and poroids density, compared to P. pungens and Pseudo-nitzschia LMP3 (Table 1). High similarity in morphological and morphometric characters was also observed between $P$. pungens and $P$. australis cell valves or frustules. Both species share similar characters and only differ in the density of poroids (Table 1). Using TEM, P. pungens could be easily distinguished from $P$. pungiformis, $P$. fraudulenta, $P$. subfraudulenta, $P$. subpasifica, and $P$. heimii by its lack of central nodule, which could be found in the valve of those other Pseudo-nitzschia species in Seriata complex.

As a note, a study done by Casteleyn et al. (2010) revealed that $P$. pungens can further be distinguished into three different clades by using nuclear-encoded rDNA ITS, plastid-encoded rbcL sequences, and subtle differences in the ultra/nanostructures of its frustules. The study classified the clades by their geographical distribution, in which (A) clade I (P. pungens var. pungens) widely distributed in temperate waters in the Atlantic and Pacific region; (B) clade II (P. pungens var. cingulate) that have limited distribution around northeastern Pacific; and (C) clade III (P. pungens var. aveirensis) which often found in tropical to warm-temperate waters within Atlantic and Pacific oceans (Casteleyn et al., 2010). This study did not include any genetic analysis on the LMP3 specimen, but based on the distribution of P. pungens clades in Casteleyn et al., (2010) paper, the $P$. pungens LMP3 most likely belonged to the clade III (P. pungens var. aveirensis). However, a further study that involves detailed genetic analysis and a more thorough analysis of P. pungens LMP3 ultra/nanostructures is required to further determine its clade.

\subsection{Notes on the physiology and ecology of $P$. pungens}

As a member of the cosmopolitan genus of Pseudo-nitzschia, $P$. pungens was known to have a very wide geographical distribution across different climate types that includes most of the coastal area within Europe, North America, Central America, South America, East Africa, South Africa, Mediterranean, India, East Asia, and Southwest Asia, including Indonesian waters (Hasle et al., 1996; Casteleyn et al., 2008; Lelong et al. 2012). In general, $P$. pungens is often found in high density at a warm temperature, high salinity, and interestingly, in low nutrient concentration (oligotrophic) waters (Almandoz et al., 2008; Lelong et al. 2012). Even so, higher nutrient concentration, particularly silica ( $\mathrm{Si}$ ), is beneficial to $P$. pungens as it could increase the cell biomass. On the other hand, Si deficiency could trigger an increase in domoic acid production (Pednekar et al., 2018). Similarly, a higher concentration of urea $\left(\mathrm{CH}_{4} \mathrm{~N}_{2} \mathrm{O}\right)$ in the water was also known to boost the domoic acid production in $P$. pungens by up to two times higher compared with the response to a higher concentration of nitrate $\left(\mathrm{NO}_{3}-\right)$ (Lelong et al. 2012). Another important parameter for $P$. pungens growth and toxin production is $\mathrm{pH}$, in which a lower $\mathrm{pH}$ level $(<8)$ could dramatically increase the domoic acid concentration in the cells to up to five-fold (Lelong et al. 2012).

In Lampung Bay, the case of Pseudo-nitzschia outbreak or blooms hasn't been reported so far. The blooming phytoplankton species in Lampung Bay usually belong to the dinoflagellate groups, such as Pyrodinium sp., Alexandrium sp., and, quite recently, Cochlodinium (Margalefdinium) sp., in which those species also produces a harmful toxin that is dangerous to animals and humans (Mizushima et al., 2007; Thoha et al., 2015, Thoha et al., 2019). In general, Pseudo-nitzschia cells was reported to be abundant during the west monsoon or rainy season in Indonesia (Thoha et al., 2019). Additionally, according to the study by Solihin et al. (2015), the genus also responds positively towards higher temperature, higher nutrient concentration $\left(\mathrm{PO}_{4}\right.$ and $\mathrm{NO}_{3}$ ), and higher $\mathrm{pH}$ in the water column of Lampung Bay. Thus, with the rapid development of coastal cities, industries, and marine aquacultures in and around Lampung Bay, there was a chance that the blooming trend could be shifted from the toxic dinoflagellates to the potentially toxic diatoms, particularly, the Pseudo-nitzschia spp. Therefore, rapid species-level identification and monitoring on the density of Pseudo-nitzschia population technique in the Lampung Bay might soon become a necessity. That would be done to quickly determine the species and to mitigate any possible negative effects from its blooms in the bay.

\section{Acknowledgement}

The phytoplankton samples were taken from preserved samples in Reference Collection for Plankton (RCP) of the Plankton Laboratory, Research Center for Oceanography, National Research and Innovation Agency (RCO-BRIN). We would like to thank our now retired laboratory technicians, Trimaningsih, Sugestiningsih, and Elly Asnaryati, who helped collect and maintain the samples. The acid cleaned sample and TEM images were produced during 2011 training in Sarawak, hosted by the Faculty of Resource Science and Technology, Universiti Malaysia Sarawak. The training was funded by the Asian Natural Environmental Science Center, University of Tokyo and UNESCO IOC/WESTPAC organization. Special thanks to Dr Lim Po Teen as the chief organizer of the 2011 training and the co-chair of IOC-WESTPAC HAB, and Prof. Mitsunori Iwataki from the University of Tokyo for the discussions and suggestions during the training. As a note, in this paper, Arief Rachman acted as the Main Contributor (Kontributor Utama) and Hikmah Thoha as the Associate Contributor (Kontributor Anggota). 


\section{References}

Almandoz, G., Hernando, M., \& Ferrario, M. (2008). SEM observations of Pseudo-nitzschia from the Beagle Channel (Argentina): $P$. seriata in the southern hemisphere? Harmful Algae News, 38.

Barokah, G. R., Putri, A. K., \& Gunawan, G. (2016). Kelimpahan Fitoplankton Penyebab Hab (Harmful Algal Bloom) di Perairan Teluk Lampung pada Musim Barat dan Timur. Jurnal Pascapanen dan Bioteknologi Kelautan dan Perikanan, 11(2), 115-126.

Bayu, A., Rachman, A., Noerdjito, D. R., Putra, M. Y., and Widayatno, W. B. (2020). High-value chemicals from marine diatoms: a biorefinery approach. IOP Conference Series: Earth and Environmental Science, 460, 012012.

Casteleyn, G., Chepurnov, V. A., Leliaert, F., Mann, D. G., Bates, S. S., Lundholm, N., Rhodes, L., Sabbe, K. \& Vyverman, W. (2008). Pseudo-nitzschia pungens (Bacillariophyceae): a cosmopolitan diatom species? Harmful Algae, 7(2), 241-257.

Casteleyn, G., Leliaert, F., Backeljau, T., Debeer, A-E, Kotaki, Y., Rhodes, L., Lundholm, N., Sabbe, K. \& Vyverman, W. (2010). Limits to gene flow in a cosmopolitan marine planktonic diatom. Proceedings of the National Academy of Sciences, 1-6.

Cerino, F., Orsini, L., Sarno, D., Dell'Aversano, C., Tartaglione, L., \& Zingone, A. (2005). The alternation of different morphotypes in the seasonal cycle of the toxic diatom Pseudo-nitzschia galaxiae. Harmful Algae, 4(1), 33-48.

Cupp, E. E. (1943). Marine plankton diatoms of the west coast of North America. Bulletin of The Scripps Institution of Oceanography, 5(1), 1-238.

Guiry, M. D., and Guiry, G. M. (2020). AlgaeBase. Retrieved from https://www.algaebase.org.

Hallegraeff, G. (1994). Species of the diatom genus Pseudo-nitzschia in Australian waters. Botanica Marina, 37(5), 397-412.

Hasle, G. R. (1976) 6.3. Some specific preparations: 6.3.1. Diatoms. In Sournia, A. (Ed.). Phytoplankton Manual. United Nations Educational, Scientific, and Cultural Organization. Paris. France. pp. 137-142.

Hasle, G. R. (1993). Nomenclatural notes on marine planktonic diatoms. The family Bacillariaceae. Beih. Nova Hedwigia, 106, 315-321.

Hasle, G., Lange, C., \& Syvertsen, E. (1996). A review of Pseudonitzschia, with special reference to the Skagerrak, North Atlantic, and adjacent waters. Helgoländer Meeresuntersuchungen, $50(2), 131$

Hernández-Becerril, D. U. (1998). Species of the planktonic diatom genus Pseudo-nitzschia of the Pacific coasts of Mexico. Hydrobiologia, 379(1-3), 77-84.

Lelong, A., Hégaret, H., Soudant, P. \& Bates, S.S. 2012, Pseudo-nitzschia (Bacillariophyceae) species, domoic acid and amnesic shellfish poisoning: revisiting previous paradigms, Phycologia (51): 168-216.

McAleece, N., Gage, J. D., Lambshead, J., \& Peterson, G. L. J. (1997). Biodiversity Professional Statistical Analysis Software. London: The Natural History Museum \& Scottish Association of Marine Science.
Mizushima, K., Matsuoka, K., \& Fukuyo, Y. (2007). Vertical distribution of Pyrodinium bahamense var. compressum (Dinophyceae) cysts in Ambon Bay and Hurun Bay, Indonesia. Plankton and Benthos Research, 2(4), 163-174.

Orsini, L., Sarno, D., Procaccini, G., Poletti, R., Dahlmann, J., \& Montresor, M. (2002). Toxic Pseudo-nitzschia multistriata (Bacillariophyceae) from the Gulf of Naples: morphology, toxin analysis and phylogenetic relationships with other Pseudonitzschia species. European Journal of Phycology, 37(2), 247-257.

Pednekar, S. M., Bates, S. S., Kerkar, V., \& Matondkar, S. P. (2018). Environmental Factors Affecting the Distribution of Pseudonitzschia in Two Monsoonal Estuaries of Western India and Effects of Salinity on Growth and Domoic Acid Production by P. pungens. Estuaries and Coasts, 41(5), 1448-1462.

Rachman, A. (2013). Pseudo-nitzschia: Fitoplankton kosmopolit dan potensial toksik. Oseana, 38(1), 15-25.

Rivera, P. (1985). Las especies del género Nitzschia Hassall, sección Pseudo-nitzschia (Bacillariophyceae), en las aguas marinas chilenas. Gayana Bot, 42(3-4), 9-38.

Skov, J., Lundholm, N., Moestrup, O., \& Larsen, J. (1999). Leaflet no. 185: Potentially toxic phytoplankton, the diatom genus Pseudo-nitzschia (Diatomophyceae / Bacillariophyceae). In J. A. Lindsey (Ed.), ICES identification leaflets for plankton (pp. 1-23). Denmark: International Council for The Exploration of the Sea.

Sidabutar, T. (2010). Kondisi fitoplankton di Teluk Jakarta pada periode 2008-2009. In R. Muchsin (Ed.), Dinamika ekosistem perairan Kepulauan Seribu, Teluk Jakarta. (pp. 121-138). Jakarta: Pusat Penelitian Oseanografi, Lembaga Ilmu Pengetahuan Indonesia.

Solihin, A., Hasani, Q., \& Yulianto, H. (2015). Hubungan Perubahan Kualitas Air Dan Pertumbuhan Fitoplankton Berbahaya Pada Lingkungan Budidaya Ikan Di Perairan Ringgung Teluk Lampung. AQUASAINS, 3(2), 289-296.

Thessen, A. E., Dortch, Q., Parsons, M. L., \& Morrison, W. (2005). Effect of salinity on Pseudo-nitzschia species (Bacillariophyceae) growth and distribution. Journal of Phycology, 41(1), 21-29.

Thoha, H. (2010). Studi variasi musiman terhadap kelimpahan fitoplankton di perairan Teluk Jakarta 2009. In R. Muchsin (Ed.), Dinamika ekosistem perairan Kepulauan Seribu, Teluk Jakarta. (pp. 139-146). Jakarta: Pusat Penelitian Oseanografi, Lembaga Ilmu Pengetahuan Indonesia.

Thoha, H., Rachman, A., Sidabutar, T., Fitriya, N., Bayu D., M., Muawanah, Iwataki, M., Takahashi, K. \& Masseret, E. (2015). First Record of the Harmful dinoflagellate Cochlodinium polykrikoides in Lampung Bay, Indonesia. Harmful Algae News, 50, 14-15.

Thoha, H., Muawanah, Bayu Intan, M., Rachman, A., Sianturi, O. R., Sidabutar, T., Iwataki, M., Takahashi, K., Avarre, J.-C., and Masseret, E. (2019). Resting cyst distribution and molecular identification of the harmful dinoflagellate Margalefidinium polykrikoides (Gymnodiniales, Dinophyceae) in Lampung Bay, Sumatra, Indonesia. Frontiers in microbiology, 10, 1-12. doi: $10.3389 /$ fmicb.2019.00306

UNESCO/IOC/WESTPAC. (2011). Taxonomy and ecology of the diatom Pseudo-nitzschia. UNESCO IOC/WESTPAC Training workshop on taxonomy and ecology of the diatom Pseudo-nitzschia. Universiti Malaysia Sarawak. 


\section{Declarations}

\section{Funding statement}

This research did not receive any specific grant from funding agencies in the public, commercial, or not-for-profit sectors.

\section{Conflict of interest}

The authors declare no known conflict of financial interest or personal relationships that could have appeared to influence the work reported in this paper.

\section{Additional information}

Reprints and permission information is available at https:// mri.lipi.go.id

Publisher's Note: Indonesian Institute of Sciences remains neutral with regard to jurisdictional claims in published maps and institutional affiliations. 